\title{
Evaluation and Quantification of Some Trace Elements in Drinking Water by ICP-OES
}

\author{
Malik Abdalla Abdelrahman Elsheikh ${ }^{1,2 *}$
}

${ }^{1}$ Department of Chemistry, Faculty of Applied Medical Sciences (Turabah Branch), Taif University, Saudi Arabia ${ }^{2}$ Department of Chemistry, College of Sciences, Sudan University of Science and Technology, Sudan

\begin{abstract}
Trace amount of elements are common in water, some of these elements may be hazardous to human health and others may be vital to human body. Using inductively coupled plasma-optical emission spectrometry (ICP-OES) technique after 10-fold pre-concentration and acid digestion, the concentrations of 10 trace elements samples (TEs) $\mathrm{Ba}, \mathrm{Cu}, \mathrm{Cr}, \mathrm{Ni}, \mathrm{V}, \mathrm{Mn}, \mathrm{Mo}, \mathrm{Ag}, \mathrm{P}$ and Si were determined in drinking water in Turabah Province (Saudi Arabia). The concentrations of $\mathrm{Cu}, \mathrm{Cr}, \mathrm{Ni}, \mathrm{V}, \mathrm{Mn}, \mathrm{Mo}, \mathrm{Ag}$ and $\mathrm{P}$ in the samples of local and national factories were found to be below the maximum level that that recommended by World Health Organization (WHO) and Saudi Arabia Standards Organization (SASO). While, the concentrations of Ba was above and below the maximum level that recommended by WHO and SASO according to the sample source. The concentrations of $\mathrm{Ba}, \mathrm{Cu}, \mathrm{Cr}, \mathrm{Ni}, \mathrm{V}, \mathrm{Mo}, \mathrm{Ag}$, and $\mathrm{P}$ in the wells samples were below the maximum level, while the concentrations of $\mathrm{Mn}$ was above the maximum level. The analysis method was validated in terms of accuracy, precision, limit of detection (LOQ) and limit of quantification (LOD) and confirmation reliability. The recovery percent was found to be $97.5-99.7 \%$.
\end{abstract}

Keywords: Trace elements; Drinking water; Wells water; ICP-OES

\section{Introduction}

Water is an essential component for life and an important source of intake of trace elements in humans. Therefore, its quality is of great importance to human health. In Turabah province (Saudi Arabia) Local factories of water treatment are small simple units consist usually of sand filters, carbon filters and ion exchange resin. The resource of the water for these local factories is wells in the valley of Turabah. No daily quality control tests for following up the quality of water in these factories, most of the people used the water produced by local factories in cooking, were some of them used it for drinking. The quality of drinking-water is a powerful environmental determinant of health; groundwater which the source of the drinking water in Turabah province contains major ions of the trace metals and other toxic pollutants [1]. All TEs are toxic if consumed at sufficiently high levels for long enough periods. The difference between toxic intakes and optimal intakes to meet physiological needs for essential trace elements is great for some elements but it is much smaller for others. According to their biological activity some of the trace elements are classified as essential trace elements which are required in very small amounts, they play a very important role in keeping the body working effectively; on the other hand numbers of trace elements are not classified as essential trace elements due to the human nutrition and their toxicity. For example $\mathrm{Ba}$ is not considered to be an essential element for human nutrition [2], The health effects of barium depend on the level of exposure, at high concentrations, it causes vasoconstriction by its direct stimulation of arterial muscle, peristalsis as a result of the violent stimulation of smooth muscles, convulsions and paralysis following stimulation of the central nervous system, the acute toxic oral dose of $\mathrm{Ba}$ is between 3 and $4 \mathrm{~g}$ [2]. Copper is one of a relatively small group of metallic elements which are essential to human health, it is combines with certain proteins to produce enzymes that act as catalysts to help a number of body functions. Copper necessary for the development of connective tissue, nerve coverings, and bone, it acts as a reductant in the enzymes, and required for the proper functioning of many important enzyme systems [3]. On the other hand, lack of $\mathrm{Cu}$ intake causes anemia, growth inhibition, and blood circulation problems [4,5]. According to study in Chile by Olivares et al. the observed level of $\mathrm{Cu}$ in drinking-water which has no effect was to be $2 \mathrm{ppm}$ [4]. Manganese is an essential element for many living organisms, including humans, for example, some enzymes require manganese, while adverse health effects can be caused by in adequate intake or over exposure of $\mathrm{Mn}$. At the median drinking-water level of $10 \mathrm{ppm}$ determined in the national inorganic and radionuclide survey, the intake of Mn would be $20 \mu \mathrm{g} / \mathrm{day}$ for an adult, assuming a daily water intake of 2 litres [5]. Large doses of Mn cause headaches, apathy, irritability, insomnia, and weakness of the legs. Long-term heavy exposure to Mn may result in a nervous system disorder [5-7]. Nickel is considered to be probably essential trace element to human health, because it might play a role in the regulation of many enzymes, but a high toxicity of element is observed during high exposure that can produce diverse health effects $[5,8]$. Chromium is an example of an essential nutrient to humans that potentiates insulin action and thus influences carbohydrates, lipid and protein metabolism $[5,9]$. Molybdenum is considered as essential metal in both animals and humans, safe and adequate intake levels have been suggested for various segments of the population, it was found to be for infants 0.015 $0.04 \mathrm{mg} /$ day, for children aged 1-10 was $0.025-0.15 \mathrm{mg} / \mathrm{day}$ and for all individuals above the age of 10 was $0.075-0.25 \mathrm{mg} /$ day [10]. Silicon is major constituent of the mammalian diet derived from cereals and cereal-based products, natural water contain soluble silicates (mostly orthosilicic acid) generally at 1-20 ppm [11]. Silicon plays a role in bone matrix formation and bone mineralization, the main known biological actions of $\mathrm{Si}$ are related with collagen, elastine and proteoglycans [12], silicon can affect the concentration of $\mathrm{Al}$ in drinking water, the significant correlation between $\mathrm{Al}$ and $\mathrm{Si}$ concentrations suggests that

*Corresponding author: Malik Abdalla Abdelrahman Elsheikh, Department of Chemistry, Faculty of Applied Medical Sciences (Turabah Branch), Taif University, Saudi Arabia, Tel: +966559839802; E-mail: malikabdalla@yahoo.com

Received February 25, 2016; Accepted June 27, 2016; Published June 30, 2016

Citation: Elsheikh MAA (2016) Evaluation and Quantification of Some Trace Elements in Drinking Water by ICP-OES. J Environ Anal Toxicol 6: 382. doi:10.4172/2161-0525.1000382

Copyright: @ 2016 Elsheikh MAA, et al. This is an open-access article distributed under the terms of the Creative Commons Attribution License, which permits unrestricted use, distribution, and reproduction in any medium, provided the original author and source are credited. 
Si can eliminate $\mathrm{Al}$ in water, and probably in the body it might do the same [13]. Silver average concentrations in USA in natural waters are $0.2-0.3 \mu \mathrm{g} / \mathrm{L}$, in Canadian tap water, only $0.1 \%$ of the samples contained more than 1-5 ng/L of Ag [13].

Elsheikh et al. [14] studied the concentration of 12 TEs $\mathrm{Na}, \mathrm{K}, \mathrm{Ca}$, $\mathrm{Mg}, \mathrm{Fe}, \mathrm{Zn}, \mathrm{B}, \mathrm{Al}, \mathrm{Pb}, \mathrm{Cd}$, As and $\mathrm{Sr}$, in drinking water of Turabah Province, they found that the concentration of some TEs are blew the maximum level recommended by WHO and SASO while others elements concentrations are above the maximum level. Electrochemical method was used for determination the concentration of $\mathrm{Pb}, \mathrm{Cd}, \mathrm{Cu}$, $\mathrm{Zn}, \mathrm{Fe}$, Se in the tap water of Jeddah city (Saudi Arabia), the obtained results were lower than the average range of these elements in the maximum concentration as they were allowed to be by WHO [15]. Trace elements such as $\mathrm{Al}, \mathrm{B}, \mathrm{Ba}, \mathrm{Cd}, \mathrm{Cr}, \mathrm{Cu}, \mathrm{Mn}, \mathrm{Pb}$ and $\mathrm{Zn}$ were studied by Momen et al. [16] in human blood samples from occupants of urban populations of Taif city (Saudi Arabia), the results of the study showed that the mean concentrations of the $\mathrm{Al}, \mathrm{B}, \mathrm{Ba}, \mathrm{Cd}, \mathrm{Cu}$ and $\mathrm{Pb}$ in human blood of diabetic mellitus and hypertensive patients were higher than the corresponding values of normal subjects. Zahid [17] studied the quality of drinking water in Riyadh city (Saudi Arabia) The results show that the most of the elements concentrations are in standard range of WHO and SASO. Tayyeb et al. studied the concentrations of $\mathrm{Zn}, \mathrm{Cr}$ and $\mathrm{Cd}$ in the commercially available drinking water in Makkah and Jeddah cities (Saudi Arabia), they found that the concentration $s$ of these elements are within the maximum permissible levels for the drinking water recommended by WHO and SASO [18].

Different Techniques have been developed for the analysis of trace elements to increase the accuracy of the low amount in matrices. Some factors affect the choice of an analytical technique, including susceptibility to matrix effects, the range of elements covered the detection limits and suitability for the matrix of interest. The usefulness of an analytical method for TEs analysis also depends on the range of elements covered and the order of magnitude of its DL for the elements at the top and bottom of its sensitivity range. Detection limits will not be the same for all elements, so that simultaneous multielements determination will require compromises in experimental conditions that will affect the accuracy and precision of at least a few elements [7].

Inductively Coupled Plasma-Optical Emission Spectrometry (ICP-OES) has become the technique of choice in many analytical laboratories for providing the accurate and precise measurements with large linear dynamic range. It is used to determine metals and some nonmetals in solution. This method is a consolidation of existing methods for water, and can be used to determine dissolved analytes in aqueous samples after suitable filtration and acid preservation $[19,20]$. Some trace elements present in very low concentration, this is depending on the type of the sample and it is source. In this case preconcentration is necessary to reach the low DL.

The present study aimed to determine and evaluate the concentration of trace elements including $\mathrm{Ba}, \mathrm{Cu}, \mathrm{Cr}, \mathrm{Ni}, \mathrm{V}, \mathrm{Mn}, \mathrm{Mo}$, $\mathrm{Ag}, \mathrm{P}$ and $\mathrm{Si}$ in drinking water samples of local (LF), national (NF) factories and wells from Turabah Province (Saudi Arabia) by using ICP-OES, and to compare the obtained values with those values that recommended by WHO and SASO.

\section{Materials and Methods}

\section{Reagent and glassware's}

The reagents and chemicals were obtained from Merck (Darmstadt, Germany, www.merck.de), are analytical grade. De-ionized doubly distilled water (DDDW) and nitric acid $(69-72 \%(\mathrm{~m} / \mathrm{m}), \mathrm{d}=1.41$ $1.51 \mathrm{~kg} \mathrm{l}^{-1}$ ) was used. Acid-washed polyethylene bottles were used for preparing and storing solutions. All solutions were stored in the refrigerator until needed for analysis. Polyethylene storage bottles, glassware and the auto sampler cups were cleaned by soaking in 5 mole $\mathrm{l}^{-1} \mathrm{HNO}_{3}$ for about $24 \mathrm{hrs}$, rinsing five times with DDDW, dried, and stored in a class-100 laminar-flow hood.

\section{Samples collection and preparation}

Forty tow samples were collected from six wells, three local factories and two national factories (1000 $\mathrm{cm}^{3}$ of each). The samples kept in polyethylene storage bottles (metal free containers) after socking the bottles in dilute nitric acid ( 5 mole $\mathrm{l}^{-1} \mathrm{HNO}_{3}$ ) overnight and washed with DDDW and then washed three times with the collected water sample before taken. The samples were filtrated through a $0.45 \mu \mathrm{m}$ pore diameter membrane filter at the time of collection and the $\mathrm{pH}$ of each sample was measured then maintained in the refrigerator.

One hundred $\mathrm{cm}^{3}$ of each well sample was transferred into $250 \mathrm{~cm}^{3}$ conical flask, while five hundred $\mathrm{cm}^{3}$ of each sample of local factories and national factories was transferred into $1000 \mathrm{~cm}^{3}$ conical flask. 5 $\mathrm{cm}^{3}$ of $5.0 \% \mathrm{HNO}_{3}$ was added to it and then evaporated to about 10 $\mathrm{cm}^{3}$ by using adjustable hot plate $\left(95^{\circ} \mathrm{C}\right)$. The sample was cooled and transferred to $50 \mathrm{~cm}^{3}$ volumetric flask. The residue was washed with 5 $\mathrm{cm}^{3}$ of $5.0 \% \mathrm{HNO}_{3}$ and with DDDW, and the volume was completed with DDDW to the mark. All prepared samples were maintained in the refrigerator until needed for analysis.

\section{Instrumentation and conditions}

The concentrations of the standards and trace elements, $\mathrm{Ba}, \mathrm{Cu}, \mathrm{Cr}$, $\mathrm{Ni}, \mathrm{V}, \mathrm{Mn}, \mathrm{Mo}, \mathrm{Ag}, \mathrm{P}$ and $\mathrm{Si}$ were analyzed by using A Varian $725-\mathrm{ES}$ inductively coupled plasma-optical emission spectrometer (ICP-OES), with radial viewing configuration (Perkin Elmer, USA). The ICP-OES operating conditions were well optimized and carefully selected in order to maximize the sensitivity for the desired elements and to obtain the best precision and accuracy. Details of the operating conditions are summarized in Table 1. The LOD and the LOQ from $1 \% \mathrm{HNO}_{3}$ for the determined element are shown in Table 2.

\section{Statistical analysis}

The results were statistically evaluated by Student $t$-test and ANOVA test $(p=0.05)$. The Microsoft Excel and Origin software's were also used to assess the significance of the differences between the variables investigated in well, local and national factories samples. The concentration values obtained were expressed as mean value \pm standard deviation $(p=0.05)$. All statistical analyses were based upon triplicate measurements of all standards and sample solutions.

\section{Results and Discussion}

The results were expressed as $x \pm s$, where $x$ is a mean values and $s$ is standard deviation. The method was validated in terms of accuracy, precision, LOD, LOQ and confirmation reliability [21,22]. The recoveries percentage (\%) was found to be $97.5-99.7 \%$. The LOD and the LOQ from $1 \% \mathrm{HNO}_{3}$ for the determined elements was shown in Table 2. The relative standard deviations (RSDs) for the samples were show in Tables 3A and 3B. The method was validated from the results of recoveries\%, LOD, LOQ and RSDs, and it found to be reliable, accurate and precise.

The $\mathrm{pH}$ of the all samples were found to be within the recommended range $(\mathrm{pH}=6.5-8.5)$. The concentrations values of $\mathrm{P}, \mathrm{Cu}, \mathrm{Mo}, \mathrm{Cr}$ and $\mathrm{Ba}$ 
Citation: Elsheikh MAA (2016) Evaluation and Quantification of Some Trace Elements in Drinking Water by ICP-OES. J Environ Anal Toxicol 6: 382. doi:10.4172/2161-0525.1000382

\begin{tabular}{|l|c|}
\hline Parameters & Conditions \\
\hline Power (KW) & 1.20 \\
\hline Plasma flow rate (L/min) & 15.0 \\
\hline Auxiliary Flow (L/min) & 1.50 \\
\hline Viewing height (mm) & 10 \\
\hline Nebulizer Pressure (KPa) & 250 \\
\hline Replicate read time (s) & 7 \\
\hline Sample uptake delay (s) & 30 \\
\hline Pump rate (rpm) & 20 \\
\hline Rinse time (s) & 25 \\
\hline Replicates & 3 \\
\hline
\end{tabular}

TEs=Trace Elements

Table 1: ICP-OES operating parameters for determination of selected TEs.

\begin{tabular}{|c|c|c|c|}
\hline Element & Wavelength $(\mathbf{n m})$ & LOD & LOQ \\
\hline $\mathrm{P}$ & 213.618 & 0.014014 & 0.03685 \\
\hline $\mathrm{Cr}$ & 267.716 & 0.0013 & 3.37246 \\
\hline $\mathrm{Cu}$ & 327.395 & 0.0013 & 3.11014 \\
\hline $\mathrm{Mo}$ & 379.825 & 0.0051 & 13.4007 \\
\hline $\mathrm{Ti}$ & 334.941 & 0.0006 & 1.3958 \\
\hline $\mathrm{V}$ & 292.401 & 0.0016 & 4.2951 \\
\hline $\mathrm{Ni}$ & 231.604 & 0.0053 & 12.4232 \\
\hline $\mathrm{Si}$ & 288.158 & 0.00858 & 0.01951 \\
\hline $\mathrm{Ba}$ & 455.403 & 0.0005 & 1.1847 \\
\hline $\mathrm{Ag}$ & 338.289 & 0.0035 & 8.90134 \\
\hline
\end{tabular}

LOD=Limit of Detection; $L O Q=$ Limit of Quantification

Table 2: LOD and LOQ for determination of selected TEs.

\begin{tabular}{|c|c|c|c|c|c|}
\hline \multicolumn{5}{|c|}{ RSD } & \multirow{3}{*}{ Element } \\
\hline \multicolumn{2}{|c|}{$\begin{array}{c}\text { National factories } \\
\text { samples }\end{array}$} & \multicolumn{3}{|c|}{ Local factories samples } & \\
\hline 2 & 1 & 3 & 2 & 1 & \\
\hline 2.8 & ND & 8.88 & 8.33 & 1.41 & $\mathrm{P}$ \\
\hline ND & ND & ND & 7.69 & 3.44 & $\mathrm{Cu}$ \\
\hline 5.41 & ND & 2.94 & 3.57 & 9.09 & Mo \\
\hline ND & ND & ND & ND & 11.11 & $\mathrm{Cr}$ \\
\hline 1.90 & 6.41 & 0.97 & 3.35 & 8.00 & $\mathrm{Ba}$ \\
\hline ND & ND & ND & 7.14 & ND & $\mathrm{Mn}$ \\
\hline ND & ND & ND & 5.56 & 6.25 & $\mathrm{Ni}$ \\
\hline 10 & ND & 5.88 & 5.88 & 10 & $\mathrm{Ti}$ \\
\hline ND & ND & 6.25 & ND & ND & $\mathrm{V}$ \\
\hline ND & ND & ND & 4.35 & 8.70 & $\mathrm{Ag}$ \\
\hline 5.90 & 5.63 & 2.15 & 1.37 & 1.07 & $\mathrm{Si}$ \\
\hline
\end{tabular}

ND=Not Detected

Table 3A: The relative standard deviation (RSD) for the factories samples.

of the local factories and the national factories samples were shown in Tables $4 \mathrm{~A}$ and $4 \mathrm{~B}$ (Figures $1 \mathrm{~A}$ and $1 \mathrm{~B}$ ). The results show that all the concentrations were below the maximum level that recommended by WHO and SASO (Table 5). However, the concentration of Ba of national factory (1) are below the maximum level that recommended by SASO but it is above the maximum level that recommended by WHO, while it is concentrations values of the local factory(3) and national factory(2) (Table $4 \mathrm{~A}$ ) are above the maximum level that recommended by WHO and SASO. The concentrations values of $\mathrm{Ba}$ of the local factory(3) was $5.1354 \pm 0.05 \mathrm{ppm}$ which seems to be higher than the maximum concentration found in groundwater in the Netherlands $2.5 \mathrm{ppm}$, in drinking-water in Canada $0.086 \mathrm{ppm}$, in water supplies of cities in the USA $0.043 \mathrm{ppm}$, and in drinking-water in Norway was to be $0.09 \mathrm{ppm}[2]$. The higher Ba concentration could affect the human's health and for long-term exposure may cause death.
The concentrations values of the elements $\mathrm{Mn}, \mathrm{Ni}, \mathrm{Ti}, \mathrm{Ag}$ and $\mathrm{Si}$ of the all factories samples were shown in Table 5 (Figures 1C and 1D), the results show that all the concentrations were below the maximum level that recommended by WHO and SASO. However; Figure 1D show the high concentrations values of $\mathrm{Si}$, which have no limit listed by WHO and SASO.

Tables $6 \mathrm{~A}$ and $6 \mathrm{~B}$ (Figures $2 \mathrm{~A}$ and $2 \mathrm{~B}$ ) show the concentrations values of wells samples of the elements $\mathrm{Ba}, \mathrm{P}, \mathrm{Cu}, \mathrm{Mo}, \mathrm{Cr}, \mathrm{Ti}, \mathrm{V}$ and $\mathrm{Ag}$, the results show that all the concentrations are below the maximum level. Table 6C (Figures 2C and 2D) show the concentrations values of $\mathrm{Mn}$ and $\mathrm{Si}$ of wells samples, The results show that the concentrations of $\mathrm{Mn}$ are above the maximum level that recommended by WHO and $\mathrm{SASO}$, as mentioned before $\mathrm{Mn}$ in large doses and Long-term heavy exposure could affect the human health, An epidemiological study was conducted in Greece to investigate the possible correlation between long-term (i.e., more than 10 years) $\mathrm{Mn}$ exposure from water and neurological effects in elderly people [6].

Figure 2D show the high concentrations values of $\mathrm{Si}$, as mentioned before, in drinking water no limit listed by WHO and SASO, but Si is considered as an essential element, and it has significance effect in dialysis patients. In these patients $\mathrm{Si}$ concentrations were significantly higher than those noted in subjects with normal renal function as well as in patients with chronic renal failure not yet in dialysis and patients treated by continuous ambulatory peritoneal dialysis [23]. However, human health risk in some patients could relate to high $\mathrm{Si}$ concentrations in drinking water.

\section{Conclusions}

According to the drinking water guide line recommended by $\mathrm{WHO}$ and SASO, the concentrations obtained of TEs of the local and national factories samples are blew the maximum level recommended, except Ba which in a some samples is above the maximum level recommended by SASO. More over the results obtained of the some wells samples of trace element $\mathrm{Mn}$ are above the maximum level recommended by both WHO and SASO. Silicon was detected in all samples, in some samples with high concentrations so intensive study on it is toxicity, human risk and formula is recommended.

\section{Acknowledgements}

The authors gratefully thank the dean of the Deanship of Scientific Research Taif University, Saudi Arabia for sponsoring this project. Also, we acknowledge all the individuals who kindly participated in the study including the staff of $\mathrm{CPL}$

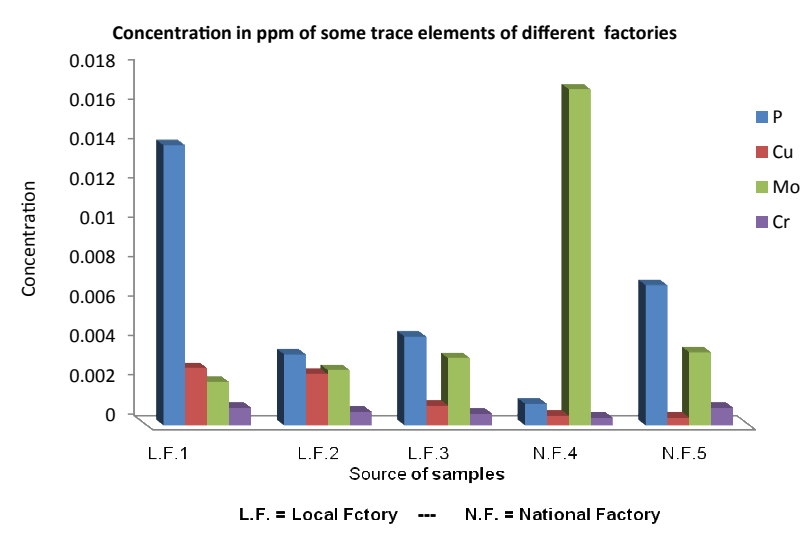

Figure 1A: Concentrations (ppm) of some TEs of different factories samples. 
Citation: Elsheikh MAA (2016) Evaluation and Quantification of Some Trace Elements in Drinking Water by ICP-OES. J Environ Anal Toxicol 6: 382. doi:10.4172/2161-0525.1000382

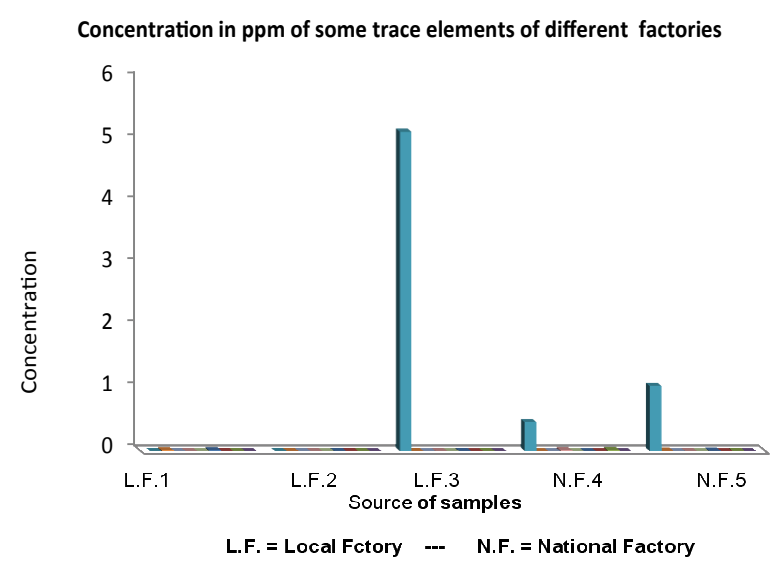

Figure 1B: Concentrations (ppm) of some TEs of different factories samples.

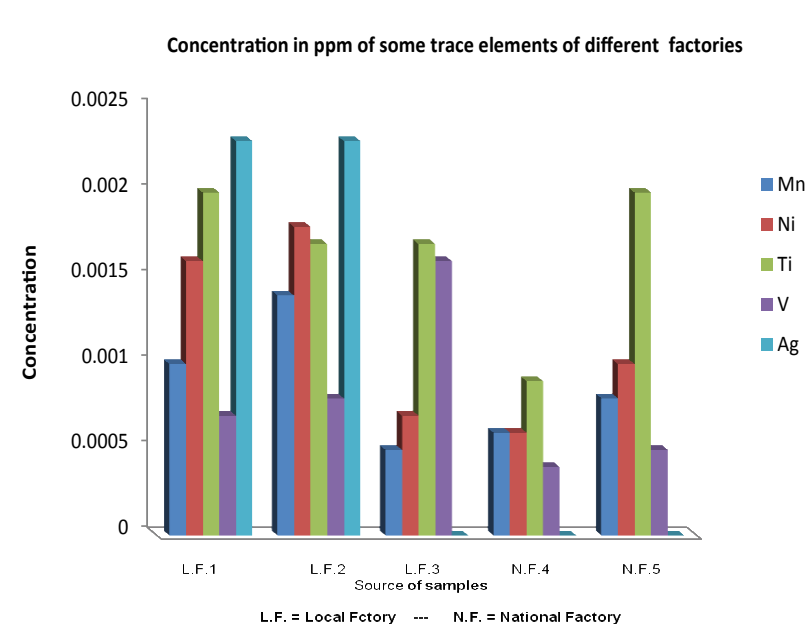

Figure 1C: Concentrations (ppm) of some TEs of different factories samples.

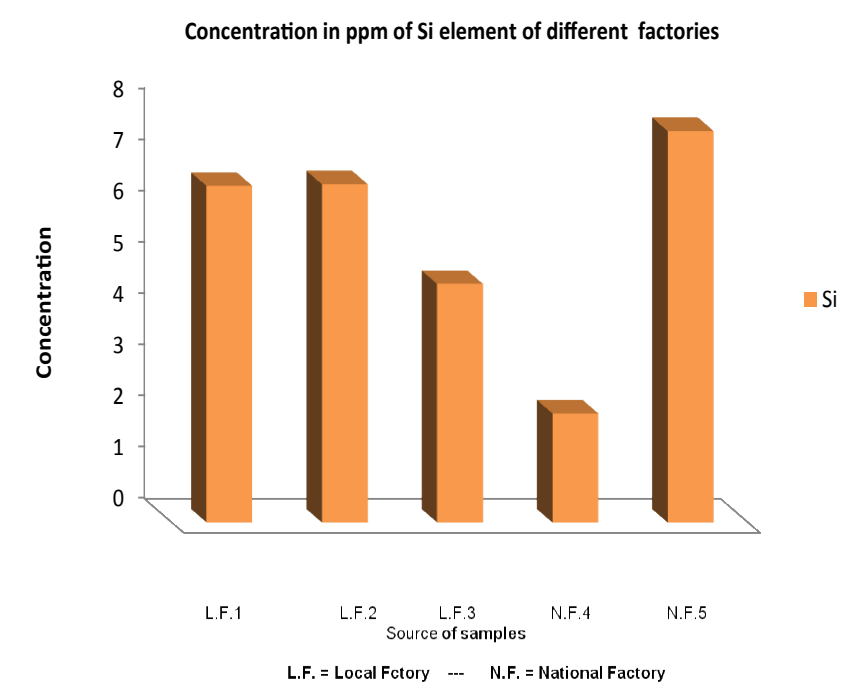

Figure 1D: Concentrations (ppm) of Si of different factories samples.

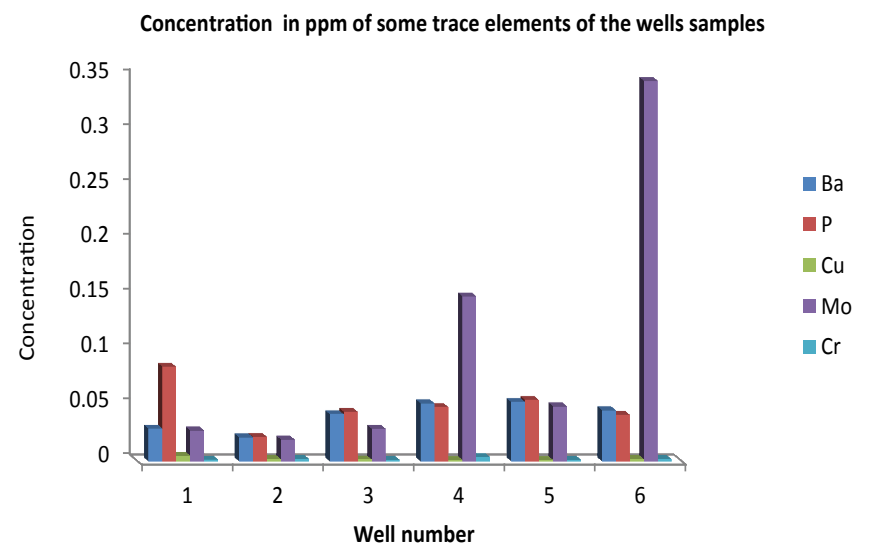

Figure 2A: Concentrations (ppm) of some TEs of wells samples.

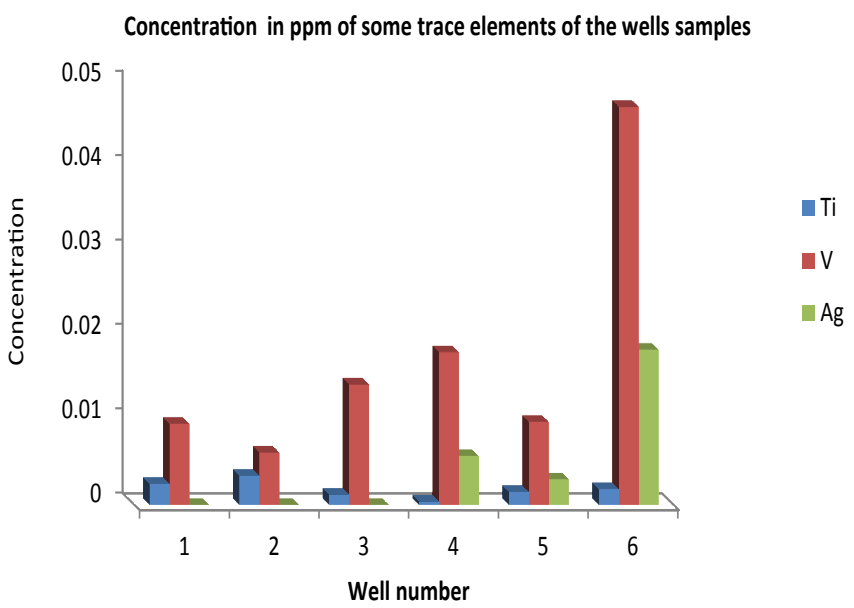

Figure 2B: Concentrations (ppm) of some TEs of wells samples.

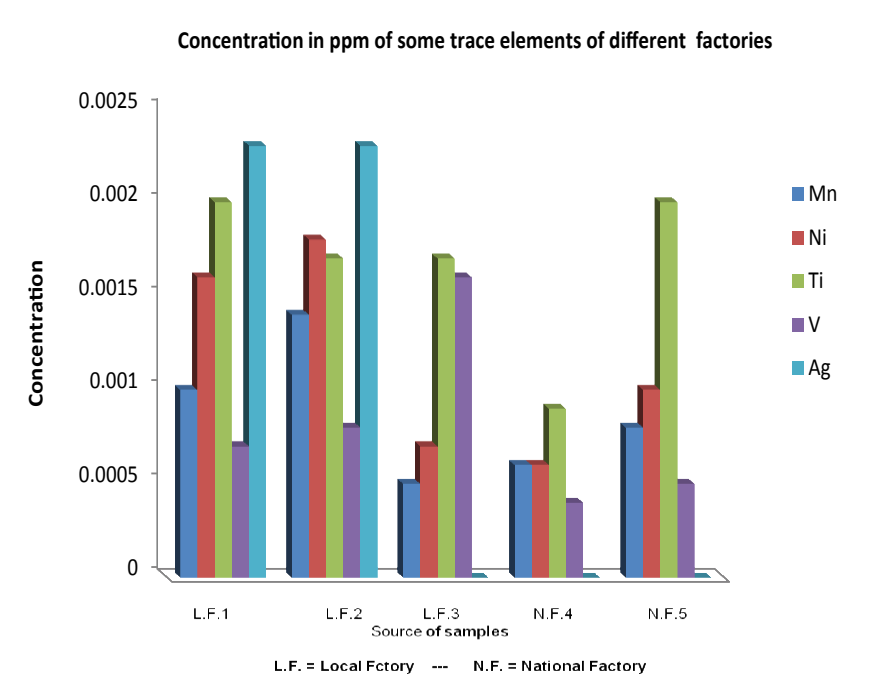

Figure 2C: Concentration in ppm of $\mathrm{Mn}$ element of the wells samples. 
Citation: Elsheikh MAA (2016) Evaluation and Quantification of Some Trace Elements in Drinking Water by ICP-OES. J Environ Anal Toxicol 6: 382. doi:10.4172/2161-0525.1000382

\section{Concentration in ppm of Si element of the wells samples}

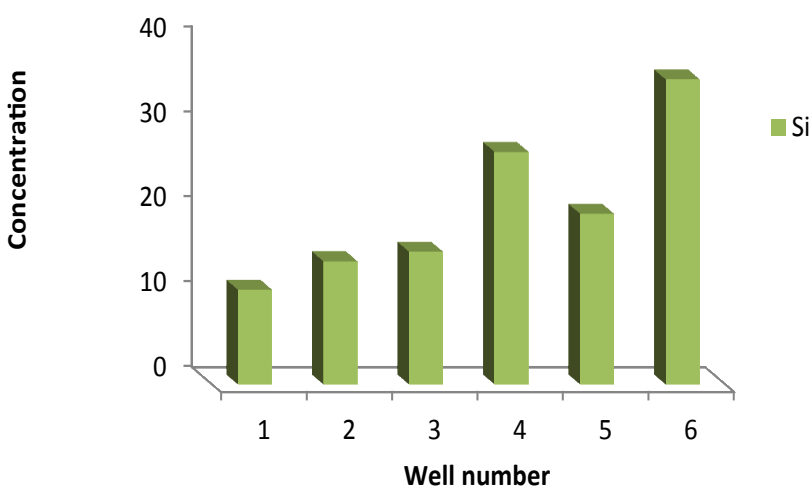

Figure 2D: Concentration in ppm of Si element of the wells samples.

\begin{tabular}{|c|c|c|c|c|c|c|}
\hline \multirow{3}{*}{ Element } & \multicolumn{6}{|c|}{ RSD } \\
\hline & \multicolumn{6}{|c|}{ Wells samples } \\
\hline & 1 & 2 & 3 & 4 & 5 & 6 \\
\hline $\mathrm{Ba}$ & 9.97 & 9.07 & 6.98 & 7.54 & 7.38 & 6.42 \\
\hline $\mathrm{P}$ & 5.80 & 4.46 & 2.21 & 4.04 & 3.57 & 7.03 \\
\hline $\mathrm{Cu}$ & 7.65 & 4.50 & ND & ND & ND & 8.23 \\
\hline Mo & 7.07 & 9.98 & 6.67 & 6.65 & 5.97 & 8.67 \\
\hline $\mathrm{Cr}$ & 5.43 & ND & ND & 4.95 & ND & 4.57 \\
\hline $\mathrm{Ti}$ & 3.98 & 8.65 & 8.13 & ND & 6.41 & 5.29 \\
\hline V & 6.24 & 4.81 & 7.00 & 5.53 & 3.05 & 4.25 \\
\hline $\mathrm{Ag}$ & ND & ND & ND & 6.92 & 9.80 & 4.90 \\
\hline $\mathrm{Mn}$ & 2.10 & 1.53 & 4.81 & 8.50 & 1.59 & 7.47 \\
\hline $\mathrm{Si}$ & 7.17 & 7.59 & 8.33 & 6.59 & 8.98 & 5.86 \\
\hline
\end{tabular}

$\mathrm{ND}=$ not detected

Table 3B: The relative standard deviation (RSD) for the wells samples.

\begin{tabular}{|c|c|c|c|c|c|}
\hline \multirow{3}{*}{ Element } & \multicolumn{5}{|c|}{ Concentration (ppm) } \\
\hline & \multicolumn{3}{|c|}{ Local factories samples } & \multicolumn{2}{|c|}{ National factories samples } \\
\hline & 1 & 2 & 3 & 1 & 2 \\
\hline $\mathrm{P}$ & $0.01417 \pm 0.0002$ & $0.0036 \pm 0.0003$ & $0.0045 \pm 0.0004$ & $0.0011 \pm 0.00$ & $0.0071 \pm 0.0002$ \\
\hline $\mathrm{Cu}$ & $0.0029 \pm 0.0001$ & $0.0026 \pm 0.0002$ & $0.001 \pm 0$ & $0.0005 \pm 0$ & $0.0004 \pm 0$ \\
\hline Mo & $0.0022 \pm 0.0002$ & $0.0028 \pm 0.0001$ & $0.0034 \pm 0.0001$ & $0.017 \pm 0$ & $0.0037 \pm 0.0002$ \\
\hline $\mathrm{Cr}$ & $0.0009 \pm 00001$ & $0.0007 \pm 0$ & $0.0006 \pm 0$ & $0.0004 \pm 0$ & $0.0009 \pm 0$ \\
\hline $\mathrm{Ba}$ & $0.0025 \pm 0.0002$ & $0.0046 \pm 0.0002$ & $5.1354 \pm 0.05$ & $0.468 \pm 0.03$ & $1.0517 \pm 0.02$ \\
\hline
\end{tabular}

a: a mean value \pm standard deviation $(n=3)$

Table 4A: Concentration (ppm) of the TEs in different factories.

\begin{tabular}{|c|c|c|c|c|c|}
\hline \multirow[t]{3}{*}{ Element } & \multicolumn{5}{|c|}{ Concentration (ppm) } \\
\hline & \multicolumn{3}{|c|}{ Local factories samples } & \multicolumn{2}{|c|}{ National factories samples } \\
\hline & 1 & 2 & 3 & 1 & 2 \\
\hline $\mathrm{Mn}$ & $0.001 \pm 0.000$ & $0.0014 \pm 0.0001$ & $0.0005 \pm 0.0000$ & $0.0006 \pm 0.0000$ & $0.0008 \pm 0.0000$ \\
\hline $\mathrm{Ni}$ & $0.0016 \pm 0.0001$ & $0.0018 \pm 0.0001$ & $0.0007 \pm 0.0000$ & $0.0006 \pm 0.0000$ & $0.001 \pm 0.0001$ \\
\hline $\mathrm{Ti}$ & $0.002 \pm 0.0002$ & $0.0017 \pm 0.0001$ & $0.0017 \pm 0.0001$ & $0.0009 \pm 0.0000$ & $0.002 \pm 0.0002$ \\
\hline V & $0.0007 \pm 0.0000$ & $0.0008 \pm 0.0000$ & $0.0016 \pm 0.0001$ & $0.0004 \pm 0.0000$ & $0.0005 \pm 0.0000$ \\
\hline $\mathrm{Ag}$ & $0.0023 \pm 0.0002$ & $0.0023 \pm 0.0001$ & ND & ND & ND \\
\hline $\mathrm{Si}$ & $6.559 \pm 0.007$ & $6.5923 \pm 0.09$ & $4.6513 \pm 0.1$ & $2.13 \pm 0.12$ & $7.6311 \pm 0.45$ \\
\hline
\end{tabular}

Table 4B: Concentration (ppm) of the TEs in different factories. 
Citation: Elsheikh MAA (2016) Evaluation and Quantification of Some Trace Elements in Drinking Water by ICP-OES. J Environ Anal Toxicol 6: 382. doi:10.4172/2161-0525.1000382

Page 6 of 7

\begin{tabular}{|c|c|c|}
\hline \multirow{2}{*}{ Element } & \multicolumn{2}{|c|}{ Concentration (ppm) } \\
\hline & WHO standard & SASO standard \\
\hline $\mathrm{P}$ & $\mathrm{NL}$ & $\mathrm{NL}$ \\
\hline $\mathrm{Cr}$ & 0.05 & 0.05 \\
\hline $\mathrm{Cu}$ & 2 & 2 \\
\hline $\mathrm{Mn}$ & 0.5 & 0.5 \\
\hline Mo & $\mathrm{NL}$ & 0.07 \\
\hline $\mathrm{Ti}$ & $\mathrm{NL}$ & $\mathrm{NL}$ \\
\hline V & $\mathrm{NL}$ & NLL \\
\hline $\mathrm{Ni}$ & 0.02 & 0.02 \\
\hline $\mathrm{Si}$ & $\mathrm{NL}$ & NL \\
\hline $\mathrm{Ba}$ & 0.3 & 0.7 \\
\hline $\mathrm{Ag}$ & $\mathrm{NL}$ & 0.1 \\
\hline
\end{tabular}

$\mathrm{NL}=$ No Limit Listed

Table 5: WHO and SASO Guide line for TEs maximum c oncentrations

\begin{tabular}{|c|c|c|c|c|c|c|}
\hline \multirow{2}{*}{ Element } & \multicolumn{4}{|c|}{ Concentration (ppm) } \\
\cline { 2 - 6 } & $\mathbf{1}$ & $\mathbf{2}$ & $\mathbf{3}$ & \multicolumn{2}{|c|}{ Wells samples } \\
\hline $\mathrm{Ba}$ & $0.0301 \pm 0.003$ & $0.02204 \pm 0.002$ & $0.04299 \pm 0.003$ & $0.05304 \pm 0.004$ & $0.0542 \pm 0.004$ & $0.04672 \pm 0.003$ \\
\hline $\mathrm{P}$ & $0.08623 \pm 0.005$ & $0.02239 \pm 0.001$ & $0.04534 \pm 0.001$ & $0.04955 \pm 0.002$ & $0.05603 \pm 0.002$ & $0.0427 \pm 0.003$ \\
\hline $\mathrm{Cu}$ & $0.00523 \pm 0.0004$ & $0.00222 \pm 0.0001$ & $0.00203 \pm 0.000$ & $0.00157 \pm 0.000$ & $0.00158 \pm 0.000$ & $0.00243 \pm 0.0002$ \\
\hline Mo & $0.02827 \pm 0.002$ & $0.02003 \pm 0.002$ & $0.02998 \pm 0.002$ & $0.15031 \pm 0.01$ & $0.05024 \pm 0.003$ & $0.346 \pm 0.03$ \\
\hline Cr & $0.00184 \pm 0.0001$ & $0.0026 \pm 0.000$ & $0.0017 \pm 0.000$ & $0.00404 \pm 0.0002$ & $0.00167 \pm 0.000$ & $0.00219 \pm 0.0001$ \\
\hline
\end{tabular}

a: a mean value \pm standard deviation $(n=3)$

Table 6A: Concentration (ppm) of the TEs in wells.

\begin{tabular}{|c|c|c|c|c|c|c|}
\hline \multirow{3}{*}{ Element } & \multicolumn{6}{|c|}{ Concentration (ppm) } \\
\hline & \multicolumn{6}{|c|}{ Wells samples } \\
\hline & 1 & 2 & 3 & 4 & 5 & 6 \\
\hline $\mathrm{Ti}$ & $0.00251 \pm 0.0001$ & $0.00347 \pm 0.0003$ & $0.00123 \pm 0.0001$ & $0.00042 \pm 0.000$ & $0.00156 \pm 0.0001$ & $0.00189 \pm 0.0001$ \\
\hline V & $0.00962 \pm 0.0006$ & $0.00623 \pm 0.0003$ & $0.014279 \pm 0.001$ & $0.018072 \pm 0.001$ & $0.00983 \pm 0.0003$ & $0.047067 \pm 0.002$ \\
\hline $\mathrm{Ag}$ & ND & ND & ND & $0.00578 \pm 0.0004$ & $0.00306 \pm 0.0003$ & $0.01837 \pm 0.0009$ \\
\hline
\end{tabular}

a: a mean value \pm standard deviation $(n=3), N D=$ not detected

Table 6B: Concentration (ppm) of the TEs in wells.

\begin{tabular}{|c|c|c|c|c|c|c|}
\hline \multirow{3}{*}{ Element } & & \multicolumn{5}{|c|}{ Concentration (ppm) } \\
\hline & & \multicolumn{5}{|c|}{ Wells samples } \\
\hline & 1 & 2 & 3 & 4 & 5 & 6 \\
\hline $\mathrm{Mn}$ & $1.9037 \pm 0.04$ & $1.9623 \pm 0.03$ & $2.2877 \pm 0.11$ & $30.6023 \pm 2.6$ & $1.2577 \pm 0.02$ & $2.3393 \pm 0.1$ \\
\hline $\mathrm{Si}$ & $11.15128 \pm 0.8$ & $14.48773 \pm 1.1$ & $15.60073 \pm 1.3$ & $27.32475 \pm 1.8$ & $20.05182 \pm 1.8$ & $35.82612 \pm 2.1$ \\
\hline
\end{tabular}

a: a mean value \pm standard deviation $(n=3)$

Table 6C: Concentration (ppm) of the TEsin wells.

Ministry of Petroleum, Khartoum, Sudan, for samples processing

\section{References}

1. Zubair A, Farooq MA, Abbasi HN (2008) Toxic and Trace Element Pollution in Storm Water of Karachi: A Graphical Approach. The Pacific Journal of Science and Technology 9: 238-253.

2. WHO (2004) Barium in Drinking-water. WHO Guidelines for Drinkingwater Quality, 20 Avenue Appia, 1211 Geneva 27 Switzerland, WHO/ SDELWSH/03.04/76.
3. Fraga CG (2005) Relevance, essentiality and toxicity of trace elements in human health. Mol Aspects Med 26: 235-244.

4. WHO (2004) Copper in Drinking-water. WHO Guidelines for Drinking water Quality WHO/SDE/WSH/03.04/88.

5. WHO (1996) Trace elements in human nutrition and health. WHO Library Cataloguing in Publication Data. ISBN 9241561734.

6. WHO (2011) Manganese in Drinking-water. WHO Guidelines for Drinkingwater Quality, 20 Avenue Appia, 1211 Geneva 27, Switzerland, WHO/SDE/ WSH/03.04/104/Rev/1. 
Citation: Elsheikh MAA (2016) Evaluation and Quantification of Some Trace Elements in Drinking Water by ICP-OES. J Environ Anal Toxicol 6: 382. doi:10.4172/2161-0525.1000382

7. WHO (2011) Report of a WHO expert committee. pp: 1-135.

8. Horng CJ, Tsai JL, Horng PH, Lin SC, Lin SR, et al. (2002) Determination of urinary lead, cadmium and nickel in steel production workers. Talanta 56: $1109-1115$.

9. Anderson RA (1988) Essential and toxic trace elements in human health and diseases. In: Prasad AS (ed). New York, Alan RL, pp: 189-197.

10. WHO (2011) Molybdenum in Drinking-water. WHO Guidelines for Drinkingwater Quality, World Health Organization, 20 Avenue Appia, 1211 Geneva 27 Switzerland, WHO/SDE/WSH/03.04/11/Rev/1.

11. Powell JJ, McNaughton SA, Jugdaohsingh R, Anderson SHC, Dear J, et al. (2005) A provisional database for the silicon content of foods in the United Kingdom. Br J Nutr 94: 804-812.

12. Kim EJ, Bu SY, Sung MK, Choi MK (2013) Effects of silicon on osteoblast activity and bone mineralization of MC3T3-E1 cells. Biol Trace Elem Res 152: 105-112.

13. Pourgheysari H, Hajizadeh Y, Tarrahi MJ, Ebrahimi A (2015) Association between Aluminum and Silicon Concentrations in Isfahan Drinking Water and Their Health Risk Assessments. Int J Prev Med 6: 111.

14. Elsheikh MAA, Ali DMH, Momen AA, Khalid MAA (2015) Validation and Quantification of Some Trace Elements in Drinking Water and Wells from Turabah Province, KSA by ICP-OES. Int $\mathrm{J}$ Multidisciplinary and Current research 3: 13-22.

15. Arab S, Alshikh A (2010) Voltammetry Determination of Some Trace Elements in Tap Water Samples of Jeddah Area in The Kingdom of Saudi Arabia. Nature and Science 8: 292-298.
16. Momen AA, Ali DMH, Khalid MA, Elsheikh MA (2013) Assessment of digestion procedure for determination of trace elements by ICP-OES. Open Science Repository Chemistry: e70081933.

17. Zahid WM (2002) Quality of Local and Imported Bottled Water in Saudi Arabia. Journal of King Abdulaziz University - Engineering Sciences 14: 81-104.

18. Tayyeb ZA, Farid SM, Otaibi KA (2004) Trace Element Concentration of commercially Available Drinking Water in Makkah and Jeddah. JKAU: Eng Sci 15: $149-154$

19. US Environmental Protection Agency (1994) Method (EPA) 200.7: Determination of Metals and Trace Elements in Water and Wastes by Inductively Coupled Plasma-Atomic Emission Spectrometry. Revision 4.4: 1-58.

20. Emeka DO, Weltime OM (2008) Trace Elements Determination in Municipa Water Supply in Damaturu Metropolis, Yobe State, Nigeria, Bayero. Journal of Pure and Applied Sciences 1: 58-61.

21. Thompson M, Ellison SLR, Wood R (2002) Harmonized guidelines for single laboratory validation of methods of analysis (IUPAC Technical Report). Pure Appl Chem 74: 835-855.

22. Elgorashe R, Idris A, Malik A, Abdelrahman, Saeed A (2014) Facile Assay Method for Norfloxacin and Ciprofloxacin by Sequential Injection Chromatography. Acta Chromatography 26: 321-334.

23. D'Haese PC, Shaheen FA, Huraib SO, Djukanovic L, Polenakovic MH, et al. (1995) Increased silicon levels in dialysis patients due to high silicon content in the drinking water, inadequate water treatment procedures, and concentrate contamination. Nephrol Dial Transplant 10: 1838-1844. 